\title{
Reduction of nitrogen oxides by injection of urea in the freeboard of a pilot scale fluidized bed combustor
}

\author{
Koen E. Knol, Eduard A. Bramer and Marinus Valk \\ Department of Thermal Engineering. Twente University of Technology, P O Box 217, \\ 7500 AE Enschede, Netherlands \\ (Received 31 May 1989)
}

\begin{abstract}
The 'thermal deNO, process using urea has been investigated in a $1 \mathrm{MW}$ fluidized bed combustor. $\mathrm{NO}_{\mathrm{x}}$ reductions of up to $76 \%$ were obtainable by using this method. The experimental results show that urea is at least as active as $\mathrm{NH}_{3}$, which is commonly used in this application, but which is far more toxic and corrosive. Emission levels of $200 \mathrm{mg} \mathrm{m}^{-3}$ for $\mathrm{NO}_{\mathrm{x}}$ could be achieved by injecting the urea at a height of $2 \mathrm{~m}$ above the distribution plate in a molar ratio urea: $\mathrm{NO}_{\mathrm{x}}=1.5$. The $\mathrm{SO}_{2}$ emission value also appeared to be reduced when the urea was injected at a urea: $\mathrm{NO}_{\mathrm{x}}$ molar ratio $>4$.
\end{abstract}

(Keywords: fluidized beds; nitrogen compounds; thermal decomposition)

The increasing awareness of atmospheric pollution problems arising from $\mathrm{NO}_{\mathrm{x}}$ has led to the introduction of more stringent regulations concerning $\mathrm{NO}_{\mathrm{x}}$ emissions from the combustion of fossil fuels. This means that there is nowadays a greater need to investigate various low $\mathrm{NO}_{\mathrm{x}}$ technologies to attain the strict regulation values that will be required in the near future.

The technologies for low $\mathrm{NO}_{\mathrm{x}}$ emissions can be divided into two groups. One approach is to minimize the generation of $\mathrm{NO}_{x}$, e.g. by flue gas recirculation, fluidized bed combustion (staged combustion) and low $\mathrm{NO}_{x}$ burners. The other is the removal of $\mathrm{NO}_{x}$ already generated by a chemical reaction with suitable reagents.

Fluidized bed combustion (FBC) is characterized by intrinsically low $\mathrm{NO}_{\mathrm{x}}$ emissions due to the low operating temperatures, and a combustion zone with reducing components such as char. Secondary measures are therefore considered unnecessary in most cases. However, as mentioned before, legislation in the Netherlands will become increasingly strict $\left(200 \mathrm{mg} \mathrm{m}^{-3}\right)$, possibly threatening the development of FBC technology. Thus, secondary measures to reduce $\mathrm{NO}_{\mathrm{x}}$ seem to be necessary. Among these measures, the method of selective non-catalytic reduction of $\mathrm{NO}_{\mathrm{x}}$ employing Exxons's 'thermal deNO,' process is most widespread'. This method of selective reduction relies on the injection of $\mathrm{NH}_{3}$ into fuel lean combustion zones at about $950^{\circ} \mathrm{C}$. The effect of the thermal reduction of $\mathrm{NO}_{x}$ by $\mathrm{NH}_{3}$ in the presence of $\mathrm{O}_{2}$ has been demonstrated in flow reactor experiments with premixed gases ${ }^{2,3}$, and experiments with burners fired with methane, oil and coal ${ }^{4-6}$. Recently, in trying to get low $\mathrm{NO}_{x}$ emissions, the method has also been investigated at a pilot-scale FBC with injection of $\mathrm{NH}_{3}$ in the freeboard by Hampartsoumian and Gibbs ${ }^{7}$ and by Amand and Leckner ${ }^{8}$. These authors showed that the cxtent of reduction is mainly influenced by the height of the injection ports, the amount of excess air present, and the $\mathrm{NH}_{3} / \mathrm{NO}_{\mathrm{x}}$ molar ratio. These parameters were also found to be most important in flow reactor studies. Maximum reductions up to $75 \%$ were possible. So 'thermal deNO,' seems to be promising for use in FBC.

However, a main disadvantage of this reduction method is that $\mathrm{NH}_{3}$ handling needs careful attention for security, as it is a very toxic and corrosive gas. The demand for a more 'human' selective reducing agent is therefore growing.

The objective of this paper is to investigate the efficacy of the application of urea instead of $\mathrm{NH}_{3}$ as a reagent for the 'thermal deNO $\mathrm{N}_{\mathrm{x}}$ process'. Urea is a cheap non-toxic, non-corrosive bulk chemical that is easy to handle.

In some patents ${ }^{9-16}$, the use of urea as $\mathrm{NO}_{x}$ reducing agent is described, but only in relation to gas fired boilers. In this application, a special reaction unit often has to be built to create the optimal reaction conditions for the 'thermal deNO, process'. In FBC application, however, the freeboard seems to be an ideal reactor with regard to temperature and residence time, but also with sufficient turbulence to apply the selective 'deNO,' reaction.

When urea is heated up, it will dissociate. Some dissociation reactions given in the literature are ${ }^{17}$ :

$$
\begin{gathered}
3 \mathrm{H}_{2} \mathrm{~N}-\mathrm{CO}-\mathrm{NH}_{2} \stackrel{T=180-280^{\circ} \mathrm{C}}{\longrightarrow=380^{\circ} \mathrm{C}} \mathrm{C}_{3} \mathrm{~N}_{3}(\mathrm{OH})_{3}+3 \mathrm{NH}_{3} \\
6 \mathrm{C}_{2} \mathrm{~N}-\mathrm{CO}-\mathrm{NH}_{2} \stackrel{\mathrm{N}_{3}\left(\mathrm{NH}_{2}\right)_{3}}{+}+6 \mathrm{NH}_{3}+3 \mathrm{CO}_{2}
\end{gathered}
$$

As seen in these reaction equations, ammonia is produced, among other dissociation products, so urea can be used in the 'thermal deNO, process'. This paper describes pilot scale FBC experiments with urea and discusses the results obtained.

\section{EXPERIMENTAL}

\section{Experimental equipment}

The experiments were carried out in a fluidized bed 


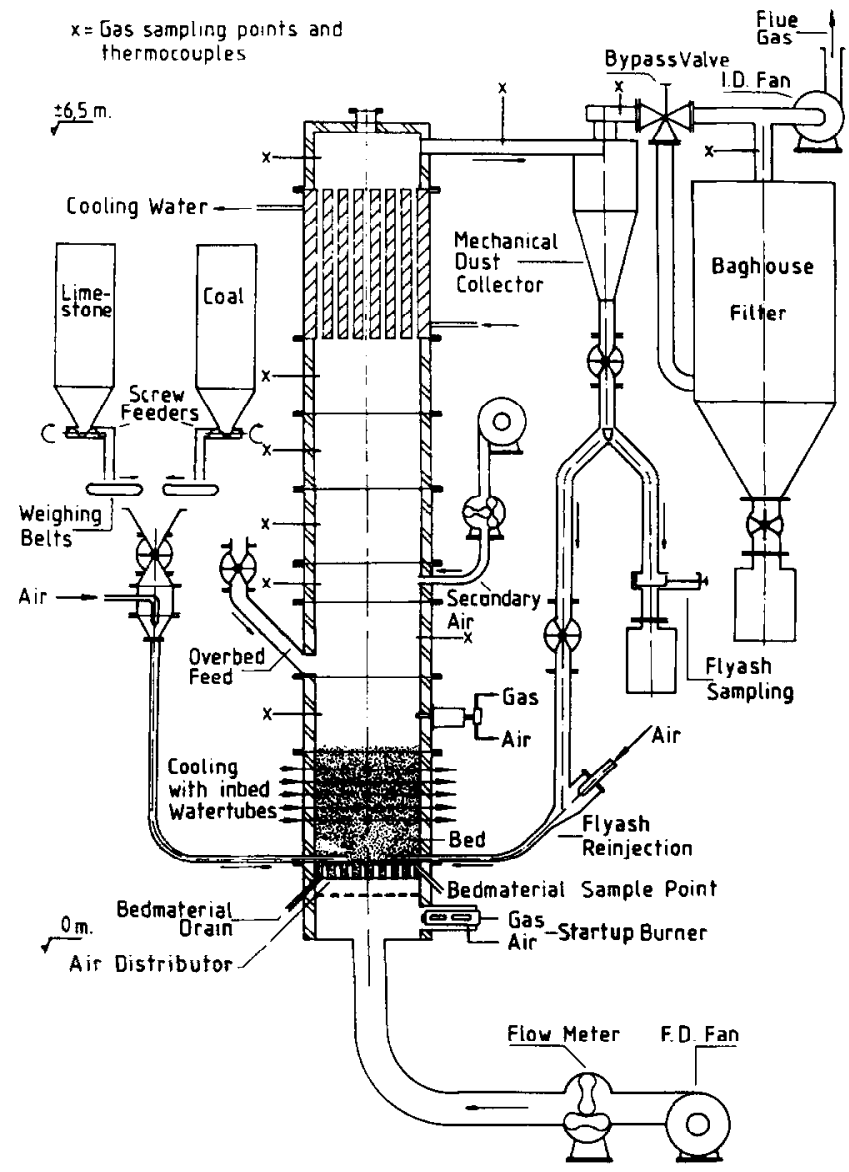

Figure 1 The fluidized bed combustor used (Twente University of Technology)

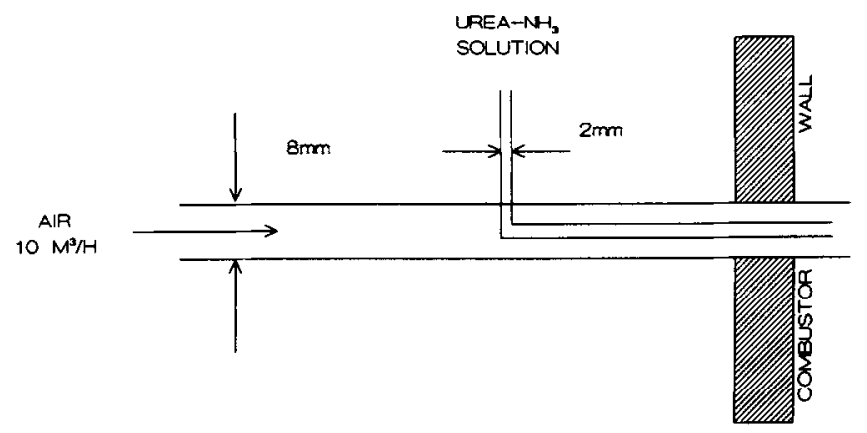

Figure 2 The injector system

combustor $\left(0.36 \mathrm{~m}^{2}\right)$, see Figure 1 . The installation is described in detail by Valk et al. ${ }^{22}$.

The urea was used in the form of an aqueous solution $(10 \mathrm{wt} \%)$, which was found to be most effective for $\mathrm{NO}_{\mathrm{x}}$ reduction (since at this concentration the urea is uniformly distributed within the effluent gas ${ }^{10}$ ). The urea solution was injected horizontally into the freeboard by a tubing pump and an air-cooled injector made of stainless steel (Figure 2), which dispersed the urea solution into a spray of fine solution droplets. This is an important step in the urea reduction process, because it enables uniform mixing of the urea with the effluent, and penetration of the urea in the freeboard.

A cooled injector system is necessary to prevent an early evaporation of the urea solution, and decomposition of urea into nitrogen oxides on steel surfaces prior to injection into the FBC.

The flue gases from the fluidized bed boiler were analysed continuously for concentrations of $\mathrm{CO}_{2}, \mathrm{CO}$,
$\mathrm{SO}_{2}$ (infrared), $\mathrm{NO}_{x}$ (chemiluminescence), $\mathrm{C}_{\mathrm{x}} \mathrm{H}_{\mathrm{y}}$ (flame ionization detection) and $\mathrm{O}_{2}$ (paramagnetic), see Figure 3. The $\mathrm{NH}_{3}$ concentration was sampled discontinuously by absorption in acidified water. The absorbed ammonium ion was determined by spectrophotometry (Berthollet's reaction).

\section{Experimental conditions}

The experiments were carried out under the conditions shown in Table 1. The bed material was silica sand. Data on the coal and limestone used are presented in Tables 2 and 3.

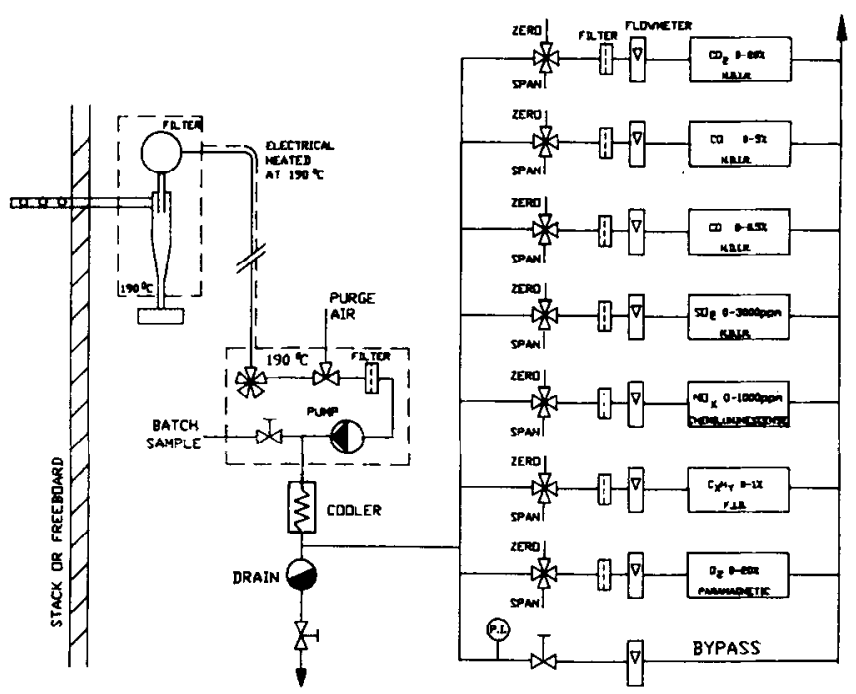

Figure 3 The continuous flue gas monitor system

Table 1 The experimental conditions

\begin{tabular}{lll}
\hline Fluidizing velocity & $: 1.8( \pm 0.2)$ & {$\left[\mathrm{m} \mathrm{s}^{-1}\right]$} \\
Bed temperature & $: 875$ & {$\left[{ }^{\circ} \mathrm{C}\right]$} \\
Freeboard temperature & $: 900$ & {$\left[{ }^{\circ} \mathrm{C}\right]$} \\
$d_{\mathrm{p}}$ bed material & $: 0.4-0.8$ & {$[\mathrm{~mm}]$} \\
Bed height (expanded) & $: 0.95$ & {$[\mathrm{~m}]$} \\
Ca/S mol ratio & $: 1.5$ & {$[-]$} \\
Coal type & $:$ Polish coal & \\
Limestone & $:$ Duwa-95 & \\
\hline
\end{tabular}

Table 2 Analysis of the Polish coal

\begin{tabular}{|c|c|c|}
\hline \multicolumn{3}{|c|}{ Ultimate analysis (dried fuel) } \\
\hline Carbon & & 77.26 \\
\hline Hydrogen & & 4.61 \\
\hline Oxygen (by di & & 7.95 \\
\hline Nitrogen & & 1.37 \\
\hline Sulphur & & 0.73 \\
\hline \multicolumn{3}{|c|}{ Proximate analysis (as received) } \\
\hline Volatile matte & & 28.4 \\
\hline Moisture & & 2.3 \\
\hline Fixed carbon & & 61.4 \\
\hline Ash & & 7.9 \\
\hline Size range & {$[\mathrm{mm}]$} & $0-10$ \\
\hline Mean diameter & {$[\mathrm{mm}]$} & 3.1 \\
\hline$<1 \mathrm{~mm}$ & {$[\%]$} & 44.0 \\
\hline
\end{tabular}

Table 3 Analysis of the Duwa-95 limestone

\begin{tabular}{lr}
\hline $\mathrm{CaCO}_{3}$ & \\
$\mathrm{MgCO}_{3}$ & 94.40 \\
$\mathrm{Si}$ & 2.91 \\
$\mathrm{Fe}$ & 0.76 \\
$\mathrm{Al}$ & 0.13 \\
$\mathrm{~K}$ & 0.14 \\
$\mathrm{~S}$ & $<0.01$ \\
Size range [mm] & 0.19 \\
\hline
\end{tabular}


The fly ash from the cyclone was partially reinjected into the bed, the recycled mass flow rate of which was controlled at 1.5 times the flow rate of the coal supplied.

Although a temperature of $950^{\circ} \mathrm{C}$ is commonly used in applying the 'thermal deNO process', a freeboard temperature of $900^{\circ} \mathrm{C}$ was chosen because Wittler $e_{t}^{t}$ al..$^{19}$ showed that this was the optimal working temperature. They postulated that the temperature characteristics were altered by heterogeneous reactions on the surfaces of particles that elutriated from the bed into the freeboard. Furthermore, we chose the urea injection port at such a height that the residence time was at least $1.5 \mathrm{~s}$, which was considered to be long enough for the selective $\mathrm{NO}_{x}$ reduction reaction ${ }^{19}$.

\section{Experimental programme}

The $\mathrm{NO}_{\mathrm{x}}$ reduction was measured as a function of the urea $/ \mathrm{NO}_{\mathrm{x}}$ molar ratio, the oxygen concentration and the height of the injecting point of the urea solution above the distribution plate. Some experiments have been carried out with an ammonia solution to compare the $\mathrm{NO}_{x}$ reduction capacity of urea with that of ammonia. Finally, we investigated which urea: $\mathrm{NO}_{x}$ and $\mathrm{NH}_{3}: \mathrm{NO}_{x}$ molar ratio gave rise to an overshoot of $\mathrm{NH}_{3}$. The experimental programme is given in Table 4. The urea: $\mathrm{NO}_{x}$ and the $\mathrm{NH}_{3}: \mathrm{NO}_{x}$ molar ratios are related to the $\mathrm{NO}_{\mathrm{x}}$ concentration at the injection point $1 \mathrm{~m}$ above the distribution plate. The $\mathrm{NO}_{\mathrm{x}}$ emission reduction is calculated from the emission level when no agent is injected in the freeboard.

\section{RESULTS AND DISCUSSION}

In Figure 4 the measured $\mathrm{NO}_{x}$ emission is given as a function of the urea: $\mathrm{NO}_{\mathrm{x}}$ ratio, whereby the urea spray was injected at a height of $1 \mathrm{~m}$ above the distribution

Table 4 The experimental programme

\begin{tabular}{lllll}
\hline Run & Reagent & $\begin{array}{l}\text { Mol } \\
\text { ratio }\end{array}$ & $\begin{array}{l}\text { Injection } \\
\text { height }[\mathrm{m}]\end{array}$ & $\begin{array}{l}\mathrm{O}_{2} \text { conc. } \\
{[\mathrm{vol} \%]}\end{array}$ \\
\hline 1 & urea & $0-10$ & 1 & 2.8 \\
2 & urea & 4 & $0.5-2$ & 2.8 \\
3 & urea & 4 & 1 & $0.9-4.0$ \\
4 & ammonia & $0-4$ & 1 & 2.8 \\
\hline
\end{tabular}

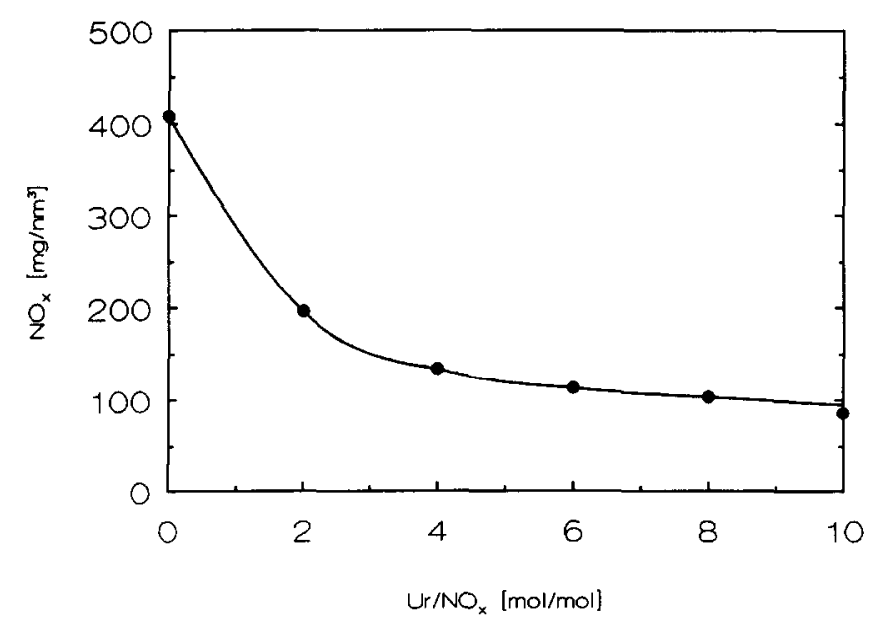

Figure 4 Reduction of the $\mathrm{NO}_{x}$ emission as a function of the urea: $\mathrm{NO}_{x}$ molar ratio. Experimental conditions: see Table 4 run 1 . Ur $=$ urea

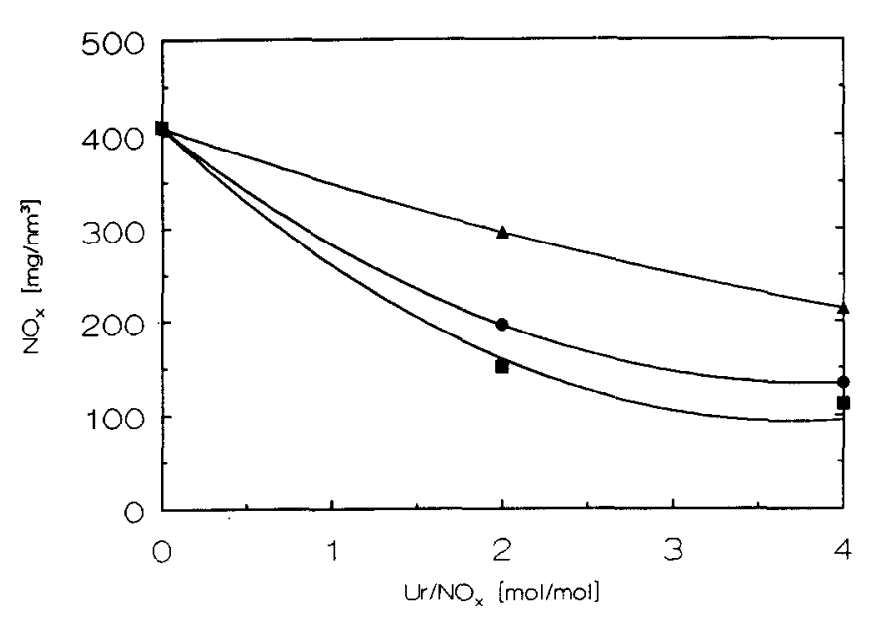

Figure 5 The $\mathrm{NO}_{\mathrm{x}}$-reduction as function of the molar ratio. Experimental conditions: see Table 4 run 2 . Ur $=$ urea. Injection height: $\Delta, 0.5 \mathrm{~m} ; \mathrm{O}, 1 \mathrm{~m} ; \mathrm{\square}, 2 \mathrm{~m}$

plate. These experimental results show that $\mathrm{NO}_{x}$ emissions can be reduced from $408 \mathrm{mg} \mathrm{m}^{-3}$ to $86 \mathrm{mg} \mathrm{m}^{-3}(76 \%)$ by injection of a urea spray with a molar ratio urea: $\mathrm{NO}_{\mathrm{x}}=10$, while an emission value of $200 \mathrm{mg} \mathrm{m}^{-3}$ is reached at a molar ratio urea: $\mathrm{NO}_{x}=2$.

Figure 5 shows the influence of the injection height of the urea spray on $\mathrm{NO}_{\mathrm{x}}$ reduction. As can be seen from this figure, the injection of the urea spray in the bed at a height of $0.5 \mathrm{~m}$ above the distribution plate, gives a much smaller reduction in $\mathrm{NO}_{\mathrm{x}}$ concentration than injection just above the bed. The best results, however, are achieved by injection $2 \mathrm{~m}$ above the distribution plate, resulting in a reduction of $72.5 \%$ of the $\mathrm{NO}_{\mathrm{x}}$ emission at a molar ratio urea: $\mathrm{NO}_{\mathbf{x}}=4$.

When the urea is injected in the bed, it will partially oxidize to $\mathrm{NO}_{x}$, which accounts for the disappointing results of the reduction of the $\mathrm{NO}_{\mathrm{x}}$ emission.

The higher $\mathrm{NO}_{\mathrm{x}}$ reduction achieved by injection at $2 \mathrm{~m}$ above the distribution plate can be explained by the lower $\mathrm{NO}_{\mathrm{x}}$ concentration at the injection port, caused by the reduction capacity of the freeboard itself (volatiles and char). The local urea:NO ratio is higher, and subsequently the $\mathrm{NO}_{\mathrm{x}}$ reduction is better. As is shown in Figure 5, a ratio of urea: $\mathrm{NO}_{\mathrm{x}}=1.5$ will be enough to achieve an emission level of $200 \mathrm{mg} \mathrm{m}^{-3}$.

The influence of the oxygen concentration on $\mathrm{NO}_{\mathrm{x}}$ reduction by urea is investigated at a molar urea: $\mathrm{NO}_{\mathrm{x}}$ ratio of 4 and an injection height of $1 \mathrm{~m}$ above the distribution plate. This influence on the $\mathrm{NO}_{\mathrm{x}}$ reduction is significant (see Figure 6). This shows that, in the oxygen concentration range $(0.9 \%-4.0 \%)$, at $0.9 \%$ oxygen a $71 \%$ reduction of $\mathrm{NO}_{\mathrm{x}}$ emission is reached $\left(100 \mathrm{mg} \mathrm{m}^{-3}\right)$, while at $4.0 \%$ oxygen the reduction is $65 \%\left(135 \mathrm{mg} \mathrm{m}^{-3}\right)$. A higher oxygen concentration probably gives rise to a higher formation of $\mathrm{NO}_{\mathrm{x}}$ due to a higher degree of urea oxidation. The reduction of $\mathrm{NO}_{\mathrm{x}}$ emissions at $4 \% \mathrm{O}_{2}$ is notable.

On comparing the $\mathrm{NO}_{x}$ reduction capacity of urea with that of ammonia, Figure 7 shows that urea is at least as active as ammonia. This is a very important result because urea is preferable to ammonia as a reducing agent.

To optimize the $\mathrm{NO}_{\mathrm{x}}$ reducing capacity of urea (and making it even greater than that of $\mathrm{NH}_{3}$ ), injection of urea powder instead of urea solution can be considered. At $330^{\circ} \mathrm{C}$, urea powder can be converted into isocyanuric 


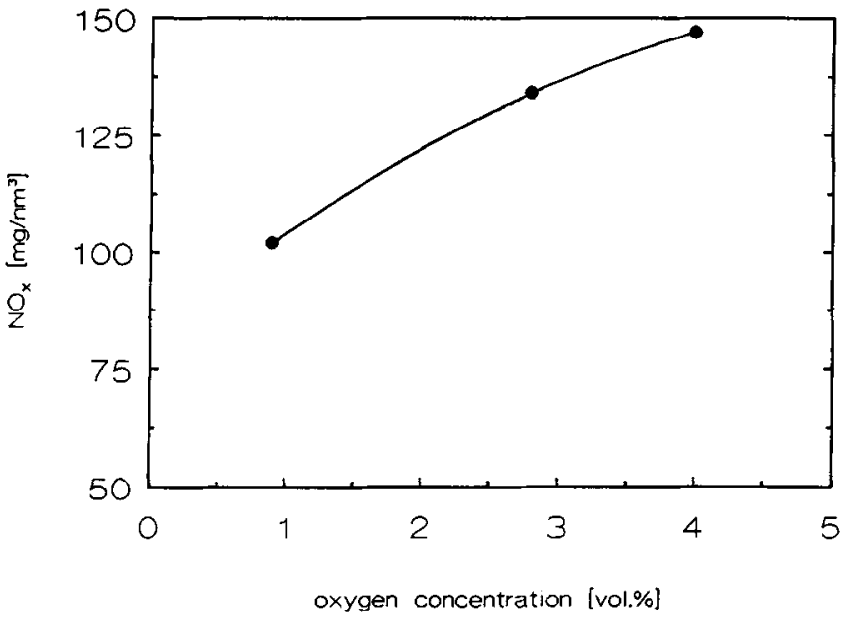

Figure 6 The influence of the $\mathrm{O}_{2}$ concentration on the $\mathrm{NO}_{\mathbf{x}}$-reduction. Experimental conditions: see Table 4 run 3

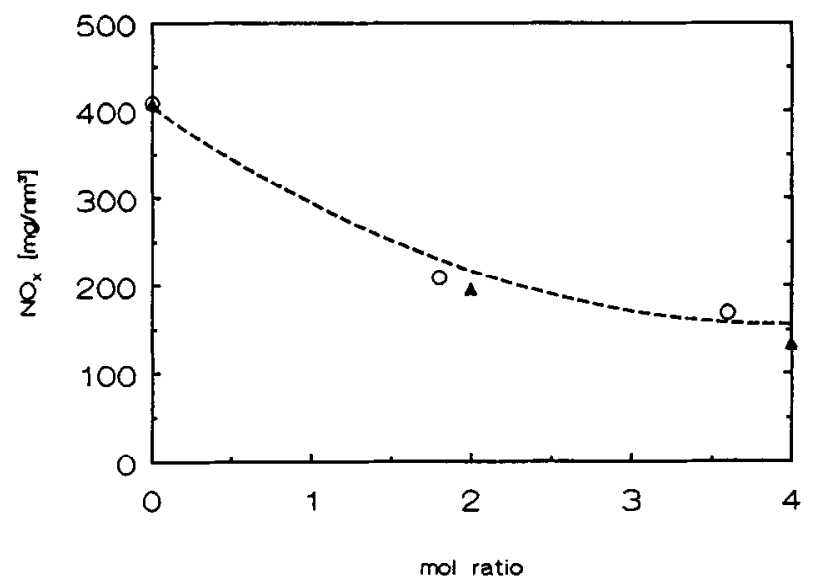

Figure 7 The NO$_{x}$-reduction by: $O$, urea; and $\Delta$, ammonia. Experimental conditions: see Table 4 runs 1 and 4

acid (HOCN) and ammonia $\left(\mathrm{NH}_{3}\right)$ by the following reactions ${ }^{20}$ :

$$
\begin{aligned}
& 3 \mathrm{H}_{2} \mathrm{~N}-\mathrm{CO}-\mathrm{NH}_{2} \stackrel{T=180-280^{\circ} \mathrm{C}}{\longrightarrow} \mathrm{C}_{3} \mathrm{~N}_{3}(\mathrm{OH})_{3}+3 \mathrm{NH}_{3} \\
& \mathrm{C}_{3} \mathrm{~N}_{3}(\mathrm{OH})_{3} \stackrel{T=30^{\circ} \mathrm{C}}{\longrightarrow} 3 \mathrm{HOCN}
\end{aligned}
$$

Isocyanuric acid is a powerful chemical reagent for the reduction of $\mathrm{NO}_{\mathrm{x}}$ emissions. At temperatures in the range $330-900^{\circ} \mathrm{C}, \mathrm{NO}_{x}$ reductions of up to $99 \%$ are obtainable by mixing isocyanuric acid with an $\mathrm{NO}_{\mathrm{x}}$-containing exhaust gas stream $^{21}$ caused by the following reaction equation:

$$
\begin{aligned}
4 \mathrm{HOCN}+4 \mathrm{NO}+\mathrm{O}_{2} \stackrel{T=330-900^{\circ} \mathrm{C}}{\longrightarrow} 4 \mathrm{~N}_{2}+2 \mathrm{H}_{2} \mathrm{O} \\
+4 \mathrm{CO}_{2}
\end{aligned}
$$

Injecting solid urea powder has the advantage over urea solution in that it ensures that HOCN is injected as well as $\mathbf{N H}_{3}$, while injecting a urea spray probably leads only to the injection of $\mathrm{NH}_{3}$ due to the reaction between urea and water, the formation of ammonium carbonate $\left(\left[\mathrm{NH}_{4}\right]_{2} \mathrm{CO}_{3}\right)$, and dissociation into $\mathrm{NH}_{3}$, $\mathrm{H}_{2} \mathrm{O}$ and $\mathrm{CO}_{2}$. Hence, it is expected that injection of solid urea will give better $\mathrm{NO}_{x}$ reduction than a urea solution.

Besides a reduction of the $\mathrm{NO}_{x}$ emission by injection of urea, we also found that above a molar ratio urea: $\mathrm{NO}_{x}=4$, the $\mathrm{SO}_{2}$ emission was greatly reduced. The reason for this could be an overshoot of the $\mathrm{NH}_{3}$ in the freeboard resulting in $\mathrm{NH}_{3}$ slipping through the freeboard. When there is $\mathrm{NH}_{3}$ in the freeboard, $\mathrm{SO}_{2}$ can react with it, resulting in the formation of $\left(\mathrm{NH}_{4}\right)_{2} \mathrm{SO}_{4}$. This will reduce the $\mathrm{SO}_{2}$ concentration. Figure 8 shows that there is indeed a relation between the $\mathrm{NH}_{3}$ concentration and $\mathrm{SO}_{2}$ reduction.

In trying to obtain evidence for this mechanism, we analysed cyclone ash for ammonium ions. However, there were none present. More research on this phenomenon therefore seems necessary.

An important fact is that urea has a much greater effect on $\mathrm{SO}_{2}$ reduction than does $\mathrm{NH}_{3}$. This is probably due to the higher concentration of $\mathrm{NH}_{2}$ radicals formed by thermal dissociation of the urea. Another important fact is that when the molar ratio of urea: $\mathrm{NO}_{\mathrm{x}}$ is $<4$, only the concentration of $\mathrm{NO}_{\mathrm{x}}$ seems to be reduced, while the $\mathrm{SO}_{2}$ concentration remains unchanged.

Due to the fact that $\mathrm{NO}_{x}$ emissions of $200 \mathrm{mg} \mathrm{m}^{-3}$ can be easily obtained on applying a molar ratio urea: $\mathrm{NO}_{\mathrm{x}}=2$, the 'thermal selective reduction' of $\mathrm{NO}_{\mathrm{x}}$ by urea will only slightly affect the $\mathrm{SO}_{2}$ emission level, and will not involve formation of corrosive ammonium sulphate.

\section{CONCLUSIONS}

From the present studies it can be concluded that the 'thermal selective reduction' of $\mathrm{NO}_{\mathrm{x}}$ by urea is as effective as reduction by ammonia. This is important since urea is much less toxic and corrosive than ammonia. It is also a relatively cheap bulk chemical, and is easy to handle and transport.

Furthermore it has been shown that the freeboard is a good reactor place with respect to temperature $\left(900^{\circ} \mathrm{C}\right)$ and residence time parameters for the thermal selective reduction' of $\mathrm{NO}_{\mathrm{x}}$ by urea. Reduction of up to $72.5 \%$ of the $\mathrm{NO}_{\mathrm{x}}$ emissions is easily obtained by the injection of the urea spray at a height of $2 \mathrm{~m}$ above the distribution plate with a molar ratio urea: $\mathrm{NO}_{\mathrm{x}}$ of 4 , without emitting $\mathrm{NH}_{3}$. By injecting the urea spray under the same conditions but with a molar ratio urea: $\mathrm{NO}_{\mathrm{x}}=1.5$, an $\mathrm{NO}_{\mathrm{x}}$ emission level of $200 \mathrm{mg} \mathrm{m}^{-3}$ can be reached.

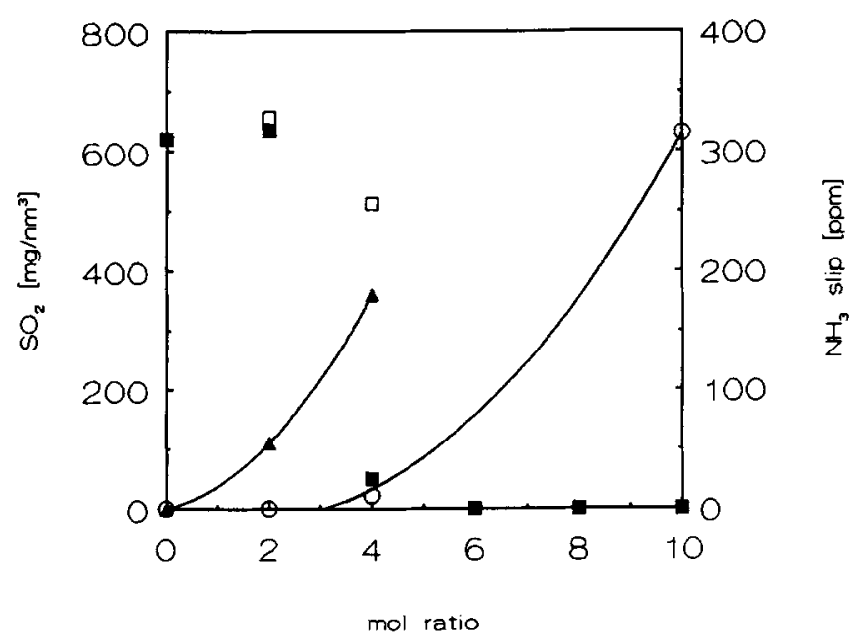

Figure 8 The $\mathrm{SO}_{2}$ - and $\mathrm{NH}_{3}$-concentrations as a function of reagent addition. Experimental conditions: see Table 4 run 1 and 4 ., $\mathrm{SO}_{2}$ urea; $\square, \mathrm{SO}_{2}$ ammonia; $\mathrm{O}, \mathrm{NH}_{3}$ urea; $\triangle, \mathbf{N H}_{3}$ ammonia 
The reduction of the $\mathrm{SO}_{2}$ concentration by urea at molar ratios urea: $\mathrm{NO}_{\mathbf{x}}>4$ deserves a more detailed investigation, and seems to be an interesting method. for reduction of both $\mathrm{NO}_{x}$ and $\mathrm{SO}_{2}$ emissions.

\section{REFERENCES}

1 Lyon, R. K. US Patent 3,900,554, August 1975

2 Lyon, R. K. and Hardy, J. E. Ind. Eng. Chem. Fundam. 1986, 25, 19

3 Lyon, R. K. Int. J. Chem. Kin. 1976, 8, 315

4 Kimball-Linne, M. A. and Hamson, R. K. Combust. and Flame 1986, 64, 337

5 Lucas, D. and Brown, N. J. Combust. and Flame 1982, 47, 219

6 Muzio, L. J., Maloney, K. L. and Arand, J. K. 17th International Symposium on Combustion, The Combustion Institute, Pittsburgh, USA, 1979, p. 89

7 Hampartsoumian, E. and Gibbs, B. M. 19th International Symposium on Combustion, The Combustion Institute, Pittsburgh, USA, 1982, p. 1253
8 Amand, L. E. and Leckner, B. Ammonia addition into the freeboard of a fluidized bed boiler, AFBC Technical Meeting, November 1986, Liege, Belgium

9 Bowers, W. E. PCT Appl. Patent WO 87-2023 Al, 9 April 1987

10 Bowers, W. E. US Appl. Patent 784.826, October 1986

11 Kreusler, H. U. Ger. Offen. Patent DE 3001457, July 1981

12 Lawson, A. A novel nitrogen oxide $\left(\mathrm{NO}_{\mathrm{x}}\right)$ control process, Preprints of the 5th Canadian Symposium on Catalysis, 1977, Ottawa, Canada

13 Azuthata, S. Ger. Offen. Patent DE 2733723, February 1978

14 Hishinuma, Y. et al. Ger. Offen. Patent DE 2630202, February 1977

15 Arand, J. K. et al. US Patent 4325924, April 1982

16 Arand, J. K. et al. US Patent 4208386, June 1980

17 'Ullman Enzyklopädie', 4. Drück., Band 9, 1985, pp. 649-653

18 Schiff, K. L. Ger. Offen. Patent 2733723, 1978

19 Wittler, W., Rotzoll, G. and Schugerl, K. Combust. and Flame $1988,74,71$

20 Sykora, R. Patent 378.358, 1983

21 Perry, R. A. and Siebers, D. L. Nature 1986, 324, 657

22 Valk, M., Bramer, E. A. and Tossaint, H. H. J. Proceedings of the Ninth Int. Conf. on Fluidized Bed Combustion, Boston, USA, 1987 , p. 784 